\title{
PELATIHAN MODEL PEMBELAJARAN PENDIDIKAN JASMANI, OLAHRAGA DAN KESEHATAN BERBASIS KARAKTER BAGI GURU PENJASORKES DI KECAMATAN BANJAR KABUPATEN BULELENG
}

\author{
oleh, \\ Made Agus Dharmadi \\ Fakultas Olahraga dan Kesehatan \\ Universitas Pendidikan Ganesha
}

\begin{abstract}
ABSTRAK
Pengabdian ini bertujuan untuk memberikan 1) pengetahuan dan pemahaman para guru penjasorkes terhadap model pembelajaran penjasorkes yang berbasis karakter, 2) perasaan dan tindakan yang berkarakter bagi siswa di sekolah dasar, sekolah menengah pertama dan sekolah menengah atas melalui penerapan pembelajaran penjasorkes berbasis karakter oleh guru. Adapun sasaran dalam penelitian ini adalah para guru penjasorkes yang ada di Kecamatan Buleleng yang berjumlah 60 orang, yang dilaksanakan di SD 6 Banjar. Metode yang digunakan adalah metode pelatihan. Dari hasil pelasanaan P2M ini dapat disimpulkan 1) adanya peningkatan pengetahuan dan pemahaman para guru penjasorkes terhadap model pembelajaran penjasorkes yang berbasis karakter, 2) perasaan dan tindakan yang berkarakter dapat terwujud melalui penerapannya secara berkelanjutan.
\end{abstract}

Kata-kata kunci: model pembelajaran penjasorkes, karakter

\begin{abstract}
This devotion aims to provide 1) knowledge and understanding of teachers' learning model Penjasorkes against character-based, 2) feelings and actions of character for students in elementary schools, junior high schools and high schools through the implementation of learning-based character Penjasorkes by teachers. The goal of this research is Penjasorkes teachers in the District Buleleng who was 60, which was held in SD 6 Banjar. The method used is the method of training. From the results it can be concluded the implementation $\mathrm{P} 2 \mathrm{M}$ 1) an increase in teachers' knowledge and understanding of the learning model Penjasorkes-based character, 2) feelings and actions that character can be realized through implementation on an ongoing basis.
\end{abstract}

Keywords: learning model penjasorkes, character

\section{Pendahuluan}

Menurut Undang-Undang Sistem Pendidikan Nasional No 20 tahun 2003, tujuan pendidikan nasional yaitu berfungsi mengembangkan dan membentuk watak serta 
peradaban bangsa yang bermartabat dalam rangka mencerdaskan kehidupan bangsa, bertujuan untuk mengembangkan potensi peserta didik agar menjadi manusia yang beriman dan bertakwa kepada Tuhan Yang Maha Esa, berakhlak mulia, sehat, berilmu, cakap, kreatif, mandiri, dan menjadi warga negara yang demokratis serta bertanggung jawab" (Sisdiknas: 2003).

Di sisi lain, pembangunan karakter yang merupakan upaya perwujudan amanat Pancasila dan Pembukaan UUD 1945 dilatarbelakangi oleh realita permasalahan kebangsaan yang berkembang saat ini, seperti: disorientasi dan belum dihayatinya nilainilai Pancasila; keterbatasan perangkat kebijakan terpadu dalam mewujudkan nilai-nilai Pancasila; bergesernya nilai etika dalam kehidupan berbangsa dan bernegara; memudarnya kesadaran terhadap nilai-nilai budaya bangsa; ancaman disintegrasi bangsa; dan melemahnya kemandirian bangsa. Untuk mendukung perwujudan cita-cita pembangunan karakter sebagaimana diamanatkan dalam Pancasila dan Pembukaan UUD 1945 serta mengatasi permasalahan kebangsaan saat ini, maka Pemerintah menjadikan pembangunan karakter sebagai salah satu program prioritas pembangunan nasional, di mana pendidikan karakter ditempatkan sebagai landasan untuk mewujudkan visi pembangunan nasional, yaitu "mewujudkan masyarakat berakhlak mulia, bermoral, beretika, berbudaya, dan beradab berdasarkan falsafah Pancasila."

Di dalam pembelajaran pendidikan jasmani, olahraga dan kesehatan (penjasorkes) dipandang sebagai upaya sadar seorang individu untuk memperoleh perubahan perilaku secara keseluruhan, baik aspek kognitif, afektif dan psikomotor. Namun hingga saat ini dalam praktiknya, proses pembelajaran penjasorkes di sekolah tampaknya lebih cenderung menekankan pada pencapaian perubahan aspek kognitif (intelektual) dan psikomotor semata yang dilaksanakan melalui berbagai bentuk pendekatan, strategi dan model pembelajaran tertentu. Sementara, pembelajaran yang secara khusus mengembangkan kemampuan afektif (atau karakter) tampaknya masih kurang mendapat perhatian. Kalaupun dilakukan mungkin hanya dijadikan sebagai efek pengiring (nurturant effect) atau menjadi hidden curriculum yang disisipkan dalam kegiatan pembelajaran yang utama. Secara konseptual maupun emprik, diyakini bahwa aspek afektif memegang peranan yang sangat penting terhadap tingkat kesuksesan seseorang dalam belajar dan bekerja maupun kehidupan secara keseluruhan 
Seringkali aspek afektif yang sudah diterapkan dalam pembelajaran tidak dilakukan secara proporsional. Hal ini membuat metode pengajaran yang digunakan terasa monoton dan tidak berkembang. Pembelajaran seperti ini akan menjadi kurang berkualitas dan cendrung membuat bosan, frustasi, dan bahkan akan membahayakan siswa. Oleh karena itu, diperlukan metode-metode pengajaran yang juga memperhatikan perkembangan afektif siswa dan mengkombinasikannya dengan perkembangan kognitif dan psikomotorik.

Menurut Popham (1995) dalam (http://amalia07.files.wordpress.com/), ranah afektif menentukan keberhasilan belajar seseorang. Orang yang tidak memiliki minat pada pelajaran tertentu sulit untuk mencapai keberhasilan belajar secara optimal. Seseorang yang berminat dalam suatu mata pelajaran diharapkan akan mencapai hasil pembelajaran yang optimal. Oleh karena itu semua pendidik harus mampu membangkitkan minat semua peserta didik untuk mencapai kompetensi yang telah ditentukan. Selain itu ikatan emosional sering diperlukan untuk membangun semangat kebersamaan, semangat persatuan, semangat nasionalisme, rasa sosial, dan sebagainya. Untuk itu, dalam merancang program pembelajaran, satuan pendidikan harus memperhatikan ranah afektif.

Keberhasilan pembelajaran penjasorkes pada ranah kognitif dan psikomotor dipengaruhi oleh kondisi afektif siswa. Siswa yang memiliki minat belajar dan sikap positif terhadap pelajaran akan merasa senang mempelajari mata pelajaran pendidikan jasmani, sehingga dapat mencapai hasil pembelajaran yang optimal. Walaupun para pendidik sadar akan hal ini, namun belum banyak tindakan yang dilakukan pendidik secara sistematik untuk meningkatkan minat siswa. Oleh karena itu untuk mencapai hasil belajar yang optimal, dalam merancang program dan kegiatan pembelajaran penjasorkes bagi siswa, pendidik harus memperhatikan karakteristik afektif siswa, dalam hal ini pembelajaran penjasorkes yang dilakukan dengan berbasis karakter sehingga secara ekplisit dapat membantu siswa untuk mengembangkan karakter yang baik pada siswa dalam berpikir, berucap dan berprilaku di dalam kehidupannya.

Di dalam program pengabdian ini, pembelajaran penjasorkes menjadi sarana untuk mewakili pembelajaran lainnya untuk di gayutkan dengan pendidikan karakter yang dimungkinkan menjadi salah solusi yang dapat ditempuh, karena di dalam pembelajaran 
penjaaskes telah termaktub unsur-unsur karakter seperti misalnya jujur, sportivitas dan saling menghargai dan lain sebagainya.

Berdasarkan beberapa informasi baik dari media cetak maupun media TV/ Radio Kecamatan Banjar yang diantaranya terdiri dari Desa Sidetapa, Cempaga, Tigawasa dan Pedawa, merupakan kelompok daerah yang cukup sering terjadi adanya persoalanpersoalan yang memicu timbulnya kekerasan dan juga kriminalitas, seperti misalnya pemberitaan yang telah terjadi akhir-ahir ini yaitu (Balipost, 8/9/2009) yang berjudul' Anak Berkelahi, Ortu Ikut Main Keroyok Di Desa Sidetapa. Lain lagi berita yang ada di Berita Bali (10/8/2011) yang berjudul Pasangan suami istri asal Desa Cempaga, Kecamatan Banjar, Buleleng menjadi korban aksi penganiayaan yang dilakukan oleh tetangganya. Ditambah lagi berita Bali Post (13/8/2011) terjadi perkelahian antar pemuda di Desa Tigewasa sehingga menyebabkan harta benda rusak parah, serta beritaberita lainya yang terdahulu menambah kesan ke-empatt daerah ini cukup menjadi perhatian pihak keamanan. Sekelumit pemberitaan di atas, sesungguhnya tidak bisa digeneralisasi, namun hasil dari beberapa informasi, pemberitaan, kejadian-kejadian yang terdahulu maupun akhir-akhir ini membuat kondisi ini telah membuat persepsi publik yang mengarah kepada karakteristik masyarakat di Kecamatan Banjar menjadi masyarakat yang berwatak sedikit 'keras'.

Berdasarkan kondisi di atas, maka melalui pembelajaran penjasorkes, program pengabdian yang berjudul 'Pelatihan Model Pembelajaran Pendidikan Jasmani, Olahraga dan Kesahatan Berbasis Karakter Bagi Guru-Guru Penjasorkes di Kecamatan Banjar Kabupaten Buleleng', menjadi sangat urgent untuk dilakukan guna membantu memperbaiki dan mempercepat serta meningkatkan proses pembenahan karakter masyarakat di Kecamatan Banjar menjadi lebih baik. Adapun rumusan masalah yang ingin dicarikan solusinya adalah: 1) Pengetahuan dan pemahaman para guru penjasorkes terhadap model pembelajaran penjasorkes yang berbasis karakter. 2) Perasaan dan tindakan yang berkarakter bagi siswa di sekolah dasar, sekolah menengah pertama dan sekolah menengah atas melalui penerapan pembelajaran penjasorkes berbasis karakter oleh guru. 3) Kesadaran moral dan etika para siswa dalam aktivitas yang dilakukan di sekolah dan di masyarakat. 


\section{Metode Pelaksanaan Pengabdian}

Di dalam program pengabdian ini, kerangka pemecahan masalah dapat dijelaskan pada gambar dibawah ini:
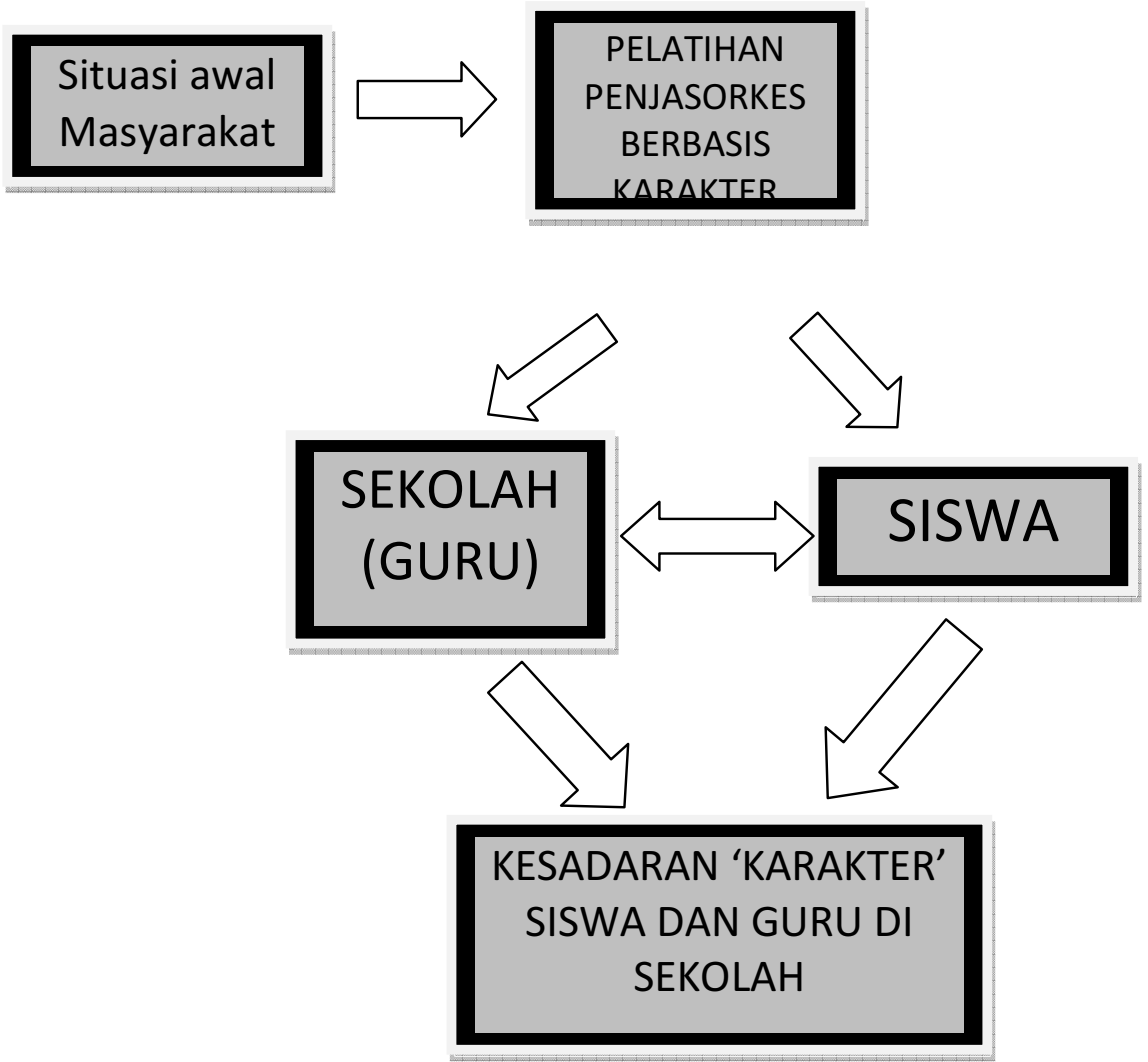

Berdasarkan bagan di atas, dapat dijelaskan bahwa program pelatihan ini secara umum memiliki tujuan utama untuk meningkatkan kesadaran moral, etika serta menumbuhkan perasaan dan prilaku yang berkarakter bagi siswa pada khususnya dan masyarakat pada umumnya. Program pengabdian ini diawali dengan pemberian pelatihan kepada guru-guru penjasorkes tentang model pembelajaran penjasorkes yang berbasis karakter, dan selanjutnya guru-guru tersebut berdasarkan hasil pelatihan kemudian menerapkannya kepada para siswa untuk secara terpadu dan kontinyu mengajarkan, membimbing dan membentuk karakter siswa dari yang jelek ke yang lebih baik, dari yang baik ke yang sangat baik. Setelah penerapan dilakukan maka selanjutnya pemahaman yang dimilik siswa diharapkan dapat menjelma menjadi sebuah kesadaran dirinya, dan juga lingkungan keluarga dan sekitarnya untuk memperbaiki 
pola-pola berpikir, berbicara dan berprilaku yang jelek menjadi yang lebih baik, sehingga dengan hal tersebut dimungkinkan nantinya masyarakatKecamatan Banjar menjadi masyarakat yang aman. Damai dan tentram sesuai dengan visi dan misi masing-masing daerah yang telah dimiliki. Metode yang digunakan dalam penelitian ini adalah metode pelatihan, bagi guru-guru penjasorkes SD, SMP dan SMA yang ada di Kecamatan Banjar .

\section{Hasil dan Pembahasan}

Berdasarkan rencana yang telah disusun, maka sebelum pelaksanaan dilakukan, maka ada beberapa hal yang harus dipersiapkan dalam pelaksanaan kegiatan nantinya, melalui rapat-rapat tim pengabdian dan juga melibatkan mahasiswa. Adapun hal-hal yang dilakukan adalah; Pertama, mempersiapkan administrasi kegiatan seperti menyiapkan surat-menyurat, melakukan observasi ke lapangan dengan menjajagi tempat pelaksanaan, menjajagi orang yang bertanggungjawab sekaligus melakukan penilaian kelayakan terhadap tempat tersebut. setelah hal tersebut kita sepakati, maka selanjutnya ditindak lanjuti dengan mengirimkan surat resmi, yang ditujukan kepada kepala sekolah guna peminjaman tempat dan fasilitas lainnya untuk penyelenggaraan pengabdian pada masyarakat. Kedua, mengirim surat undangan kepada peserta pengabdian, yaitu guru-guru SD, SMP dan SMA yang ada di kecamatan Banjar, Kabupaten Buleleng. Ketiga, menghubungi narasumber yang akan digunakan dalam pelatihan tersebut. keempat, menghubungi pihak lembaga P2M Undiksha, untuk berkenan membuka kegiatan. Serta persiapan-persiapan lainnya seperti, konsumsi, transportasi, sound system, dan yang lainnya.

\section{Tahap Pelaksanaan Kegiatan}

Pelaksanaan kegiatan pengabdian ini delakukan selama 2 hari dari persiapan hingga pelaksanaan, persiapan dilaksanakan tanggal 21 Agustus 2013, dan pelaksanaannya tanggal 22 Agustus 2013 di Desa Banjar. Kegiatan ini dilaksanakan di Aula SD 1 Kecamatan Banjar yang berkapasitas kurang lebih 150 orang. Kegiatan ini mengundang seluruh guru-guru Penjasorkes yang ada di Kecamatan Banjar dari SD hingga SMA yang berdasarkan data berjumlah 60 orang guru. Narasumber dalam Pelatihan yang bertema 'Model Pembelajaran Penjasorkes Berbasis Karakter" adalah I Ketut Yoda 
S.Pd, M.Or. Pelaksanaan pengabdian ini dimuali dari pukul 09.00 wita s/d 13.00 wita, yang dibuka oleh Sekretaris Lembaga Pengabdian Masyrakat UNDIKSHA Singaraja. Kehadiran peserta pelatihan pada saat pembukaan berlangsung hampir $100 \%$ guru yang diundang hadir, hal ini menandakan bahwa antusias guru dalam mengikuti pelatihan ini sangatlah besar.

Selanjutnya setelah pembukaan, maka dilanjutkan dengan pemaparan materi pelatihan oleh narasumber, dengan dimoderatori oleh I Kadek Happy Kardiawan, S.Pd, M.Pd. pemaparan tentang Model pembelajaran Penjasorkes Berbasis Karakter, secara gamblang disertai contoh-contoh nyata dalam kehidupan, membuat suasana pemaparan cukup terkonsentrasi dengan apa yang dipaparkan, peserta dengan seksama menyimak dan mendengarkan pemaparan dan terlihat keseriusan peserta sehingga situasi pada saat pemapaarn cukup serius, namun dengan diselingi humor-humor segar oleh narasumber, menjadikan pemaparan berlangsung seperti sangat singkat, padahal telah membutuhkan waktu kurang lebih 2,5 jam. Setelah pemaparan berakhir tiba saatnya diskusi, berdasarkan jumlah pertanyaan yang ada dapat disimpulkan bahwa diskusi yang dilakukan sangat dinamis, seorang guru dari SMA 1 Banjar (Puja Arsana), menanyakan tentang apakah pengembangan karakter dapat dituangkan kepada siswa, sedangkan RPP yang saya buat apa bisa dikembangkan pada siswa. Dari pertanyaan ini kemudian memperoleh tanggapan bahwa pengembangan karakter dalam RPP menjadi keharusan, dan dapat dituangkan pada siswa, yang perlu dilakukan guru adalah mencari metode yang baik agar maksud pengembangan karakter yang dituangkan di RPP bisa ditransfer ke siswa tanpa mengalami hambatan. Selanjutnya pertanyaan kedua datang dari guru SMP N 3 Banjar (Mariani) menanyakan tentang bagaimana karakter itu bisa dikembangkan melalui ungkapan saling menyapa antar siswa, guru dan yang lainnya, pertanyaan ini kemudian ditanggapi bahwa konsep saling menyapa merupakan konsep universal yang harus kita lakukan, dan orang yang bisa harmonis secara pikiran, perbuatan adalah orang yang jujur, dan senantiasa kita harus melakukan swadarma kita, dan guru harus menjadi teladan bagi siswanya. Pertanyaan ketiga diajukan oleh guru SD 3 Kalianget (Ketut Mangku), yang menanyakan tentang pengembangan karakter ini sangat dibutuhkan oleh guru, namun kepala sekolah juga harus mampu mengembangkannya, sehingga disarankan agar kepala sekolah dan guru-guru lainnya 
juga dilibatkan dalam pelatiahn karakter ini, karena guru penjasorkes tidak bisa berjalan sendiri, harus juga dibarengi dengan guru-guru lainnya dan juga kepala sekolah. Sehingga dari pertanyaan dan juga saran yang ada, dari seluruh wakil guru, yakni guru SD, SMP dan SMA, maka seluruh komponen telah terwakili sehingga pelatihan ini diharapkan nantinya dapat diterapkan oleh guru-guru tersebut dalam memberikan pembelajaran penjasorkes di sekolah. Akhirnya diskusi yang cukup dinamis dan ramai ini berakhir kurang lebih 1,5 jam lamanya dan terlihat dengan raut muka guru-guru yang terlihat senang dan gembira serta menyatakan pemahamannya terhadap pelatihan yang dilakukan.

\section{Tahap Penutupan Kegiatan}

Akhirnya, setelah kurang lebih 4 jam pelatihan ini dilaksanakan, maka kegiatan diakhiri dengan penutupan, dalam penutuapan ini terlihat bahwa antusiasme guru sangat tinggi, dengan bertahannya guru-guru mengikuti pelatihan ini hingga penutupan berlangsung. Penutupan ini ditutup oleh Ketua Tim P2M, yang pada intinya dalam pengarahannya mengucapkan terima kasih atas antusiame guru dalam mengikuti pelatihan, memberikan pandangan-pandangan terhadap pentingnya membangun karakter pada siswa, dan tidak luput pula menghaturkan permohonan maaf, jika di dalam pellaksanaan terdapat hal-hal yang kurang berkenan. Setelah acara ditutup, kemudian seluruh peserta dan panitia penyelenggara melakukan makan bersama, dan bersalam-salaman dengan para guru, sehingga saat itu sangat terasa rasa kekeluargaan antara guru-guru penjasorkes dan panitia (dosen, mahasiswa FOK UNDIKSHA), jalinan ini merupakan intisari dari tugas dan kewajiban kita dalam mengabdi, sehingga UNDIKSHA dapat menanamkan simpul-simpul keluarga baik itu dengan guru dan juga masyrakat pada umumnya.

\section{Penutup}

Berdasarkan pembahasan di atas, maka dapat disimpulkan bahwa (1) Kegiatan pelatihan ini dapat terlaksana dengan baik, aman dan lancer, (2) Terjadinya peningkatan pemahaman antara sebelum diberikan pelatihan dengan sesudah pelatihan, (3) Model Pembelajaran penjasorkes berbasis karakter merupakan salah satu pilar yang harus dilakukan oleh guru-guru penjasorkes melalui RPP nya sehingga siswa 
implementasinya kepada siswa dapat terwujud, (4) Kegiatan ini sangat bermanfaat bagi guru-guru penjasorkes khususunya di kecamatan Banjar, (5) Disarankan agar guru-guru lainnya dan juga kepala sekolah diberikan pelatihan tentang pengembangan karakter seperti ini juga, dan (6) Pendanaan yang terbatas mengakibatkan kegiatan ini tidak bisa mencakup lebih luas dan mendalam, sehingga disarankan agar pendanaan kegiatan P2M untuk ditingkatkan.

\section{DAFTAR PUSTAKA}

Balipost. 2009. Anak Berkelahi, Ortu Ikut Main Keroyok Di Desa Sidetapa.Tersedia pada www.balipost.co.id: diakses pada tanggal 19 Februari 2012

Balipost. 2011.Perkelahian Antar Pemuda di Tigewasa. Tersedia pada www.balipost.co.id: diakses pada tanggal 19 Februari 2012

Berita Bali. 2011. Pasangan Suami Istri Dianiaya Di Desa Cempaga. Tersedia pada www.beritabali.co.id: Tdiakses pada tanggal 19 Februari 2012

BNSP.2009. Standar Isi Kurikulum Penjasorkes. Tersedia pada http://www.bnsp.go.id: Diakses tanggal 18 Februari 2012

Moston and Ashworth. 1994. Teaching Physical Education. San Fransisco: Pearson Education Inc

Pedoman Pendidikan Karakter.2010. Pedoman Pendidikan Karater. Tersedia pada http://pendikar.dikti.go.id/gdp/wp-content/: diakses pada tanggal 19 Februari 2012

Pemda Buleleng. 2009. Selayang Pandang Desa Sidetapa, Cempaga, Tigewasa dan Pedawa. Tersedia pada www.bulelengkab.go.id: diakses pada tanggal 18 Februari 2012

Popham,1995. Model Pembelajaran Afektif . Tersedia pada http://amalia07.files.wordpress.com: diakses pada tanggal 19 Februari 2012

Undang-Undang Sistem Keolahragaan Nasional: UU RI No. 3 Tahun 2005. Jakarta: Sinar Grafika 